\title{
Early Literacy Value on Kakawihan
}

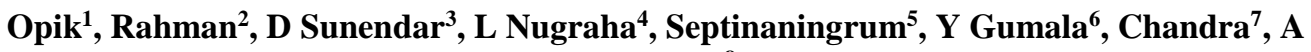 \\ Kharisma $^{8}$ \\ $\left\{{ }^{1}\right.$ gerimisculamega@yahoo.co.id, ${ }^{2}$ rahmanprofupi@upi.edu, ${ }^{3}$ dadangsunendar@gmail.com, \\ ${ }^{4}$ lukmanmifdha82@gmail.com, ${ }^{5}$ ningrumseptina@gmail.com, ${ }^{6}$ yosigumala@student.upi.edu, \\ ${ }^{7}$ chandra@fip.unp.ac.id \} \\ ${ }^{1}$ SDN 2 Cikuya Culamega, Indonesia \\ ${ }^{2,3}$ Universitas Pendidikan Indonesia Bandung, Indonesia \\ ${ }^{4}$ STAI Miftahul Huda Subang, Indonesia \\ ${ }^{5}$ IAIN Tulungagung, Indonesia \\ ${ }^{6}$ Universitas Bhayangkara Jakarta Raya, Indonesia \\ ${ }^{7}$ Universitas Negeri Padang, Indonesia \\ ${ }^{8}$ Universitas Islam Negeri Imam Bonjol, Indonesia
}

\begin{abstract}
Sundanese culture in the care of children is known as kakawihan. Realized or not, a kakawihan which is sung by parents when caring for children is the process of introducing early literacy, especially related to literacy in the scope of Sundanese culture and language. As time goes by, the flow of globalization that infiltrated every part of life in Indonesian society slowly eroded the culture of each ethnicity, including the culture of the Sundanese people, one of which was kakawihan which was used to nurture children. In this case, the researcher conducted a study aimed at obtaining a comprehensive picture of the value of early literacy in kakawihan which is used to care for children. This study uses the content analysis method. The research techniques used are in the form of document studies, observations, and interviews. Based on the results of the study, it was found that kakawihan used to care for children contained early literacy values within the scope of Sundanese language and culture. Kakawihan is used in caring for children, besides being used by the closest people, it is also done with compassion to foster phonological awareness, knowledge of letters, and children's vocabulary in Sundanese.
\end{abstract}

Keywords: Early Literacy, Kakawihan, Children, Phonological, Vocabulary

\section{INTRODUCTION}

Indonesian society is known as a pluralistic society with a diversity of cultures including regional languages as the cultural identity of each ethnic group. But as time moves, the flow of globalization that has infiltrated every part of the life of Indonesian people has slowly eroded the culture of each ethnic group, including the values in it. In this case, the regional language as the cultural identity of an area was also affected by the same, including Sundanese.

So far, from over 700 languages of various ethnic groups in Indonesia, Sundanese ranks number two, the regional language with the most speakers. However, the decline in the number of speakers and even the destruction of Sundanese as a regional language is possible. Tracing various information, decreasing the number of speakers and even the disappearance of 
regional languages in Indonesia is not something new. As many as 11 regional languages in Indonesia were declared extinctin 2018. Besides, four regional languages weredeclared critical and two regional languages were setbacks[1]. The extinct language comes from Maluku, namely the languages of the Kajeli/Kayeli, Piru, Moksela, Palumata, Ternateno, Hukumina, Hoti, Serua and Nila, and Papuan languages, namely Tandia and Mawes. While the critical languagesare the language in Reta from East Nusa Tenggara, Saponi from Papua, and Maluku, namely Ibo and Meher.

Indications of a decline in the number of speakers, if they are neglected, are likely to find ways to the extinction of Sundanese in everyday life. These can be identified, for example by beginning with decreasing Sundanese-language conversations among school children (Early Childhood Education - High School) in large cities in West Java. Even though West Java is the area from which Sundanese grows and develops.

The decline in children's conversations in using Sundanese certainly has various causes. From many causes, the authors assume because of the disappearance of parenting patterns rooted in Sundanese culture. Talking about patterns of parenting children rooted in Sundanese culture, one of how ancient parents and a small part nowadays, to nurture their children is by singing kakawihan.

According to the Dictionary of Basa Sunda thatkawih means lagu sora jelema anu euweuh pupuhna, taya patokanana[2]. While kakawihan means nyorakeun rupa-rupa kawih. Kawih means the song or voice of a person without a standard or without being bound by the rules of the pupuh. While kakawihan is singing kawih.

Kakawihan sung by parents when taking care of children (toddlers), is a bridge to teach mother tongue that has early literacy values. The early literacy referred to this paper, of course, refers to Sundanese language skills. Early literacy will provide initial literacy abilities that cover several points, some of which are as follows: (1) Grow phonological awareness for children. (2) Knowledge of letters. (3) Vocabulary. (4) Background knowledge. (5) Speaking ability[3]-[7].

Very clear early literacy values in kakawihan can be identified in kawihs which have lyrics with rhyming patterns. One of out of the 8 early literacy strategies revealed in the article explained that efforts to build early literacy could be done by providing activities that increase children's awareness of the sound of language or that words consist of the smallest sound units, namely the alphabet[3], [5], [6], [8]-[10]. These activities include playing games and listening to stories, reciting poems, and songs that involve poetry, identifying words that end with the same sound[6], [11]-[13]. Furthermore, if kakawihan of parenting children continue to be explored any value contained in them, besides being a way to preserve the culture, it also opens the eyes of the community regarding the value of early literacy in it and does not rule out the possibility in the development of theories and practices of childcare.

\section{RESEARCH METHOD}

The approach which is used in this study is qualitative. Arikunto (2009: 195 [5]) states that qualitative research is a descriptive study because this study seeks to describe data with words or sentences separated by categories to obtain conclusions. Qualitative research is research that requires researchers to examine phenomena that occur naturally in all their complexity. This study uses the content analysis method. Content analysis was a technique that can be used to study human behavior indirectly through analysis of their communication such as textbooks, essays, newspapers, novels, magazine articles, songs, advertisement images and all types of communication that can be analyzed[14]. 
The source of the data in this study was several people who had and were still living in the Sukawangi Village, Singajaya District, Garut Regency, which were completely collected and recorded by researchers. The research technique is carried out in the form of (a) Documents study by collecting kakawihan that was and is still used by the people of Sukawangi Village. Kakawihan in the form of oral literature was recorded by researchers for the needs of documents study. (b) Observation is done by observing the process of caring for children by singing kakawihan. (c) Interviews were conducted for several early literacy experts and for informants who understood the Sundanese culture, especially related to kakawihan.

\title{
3. RESULTS AND DISCUSSION
}

In the culture of Sundanese society, it used to have traditional characteristics in parenting and education for their children. The parenting and education system are taught not formally but are presented in appropriate game patterns and shaped by the characteristics of their daily lives, one of which is through kakawihan.

The term kakawihan comes from the word kawih which means song or song[15]. This term has long been known and used by Sundanese, as contained in the text Siksa Kanda $\mathrm{Ng}$ Karesian which has the following:

"Hayang nyaho disakweh ning kawih ma kawih bwatuha kawih panjang, kawih lalaguan, kawih panyaraman, kawih sisi(n)diran, kawih pangpeledan, kawih bongbongkaso, kawih pererane, porod eurih, kawih babahanan, kawih bangbarongan, kawih tangtung, kawih sasa(m)batan, kawih igel-igelan, sing sawatek kawih ma, paraguna tanya."

(If you want to know all kinds of batuha songs, kawih panjang, kawih lalaguan, kawih panyaraman, kawih sisindiran, kawih pengpeledan, kawih bongbongkaso, perane, porod eurih, kawih babahanan, kawih bangbarongan, kawih tangtung, kawih sasambat, kawih igel-igelan, every kind of song ask paraguna /karawitan expert)

From the statement above, it can be concluded that the term kawih has long been used by Sundanese society. Over time, the culture began to erode. But some of them are still surviving. Here are some of the kawih that have been and are still being used to raise children, by the people of Sukawangi Village, Singajaya District, Garut Regency, some of which are as follows:
Ayun-ayun ambing
Ayun ambing ayun ambing
Diayun-ayun ku samping

The kawih above is used by people since they took care of their babies. Usually, the parents always sing it as mépépéndé '(telling the baby to sleep), a mother or father tenderly make their child sleep with dieyong while chanting kawih Ayun Ambing.

\author{
Dug Gera Bobo \\ Dug gera bobo \\ Disampakkeun pais bogo \\ Dug gera saré \\ Disampakkeun pais lélé
}


If the baby is getting older, the kawih sung is Dug Gera Bobo. The song practically is accompanied by a hand touching, kissing on the forehead or blowing the crown of the baby.

\author{
Ucang-ucang anggé \\ Ucang-ucang anggé \\ Mulung muncang na paranggé \\ Digogog ku anjing gedé \\ Anjing gedé nu ki lebé \\ Anjing leutik nu ki santri \\ Ari gog-gog cungungung
}

When the baby is over nine months old, ordinarily it can crawl and sit. At this age, the child will be told to sit on the hanging toe of the parents', the child's hands are held, then the parents will sing kawih Ucang-ucang anggé. This game of Ucang-ucang anggé is usually done by male parents.

\title{
Jampé-jampé harupat \\ Jampé-jampé harupat \\ Geura gedé geura lumpat
}

When the child starts learning to walk, both parents (father and mother) sit face to face with a distance of about two meters, the child is told to walk from the direction of his father to his mother and continue to do back and forth. The mother will catch or nyanggap the child and turn his body towards his father. This continues to be done many times. This game is performed without being accompanied by singing, or by singing ning nang ning eu ning nang ning eu. If the child falls, his parents will immediately hug his child while rubbing the part of the body that is considered sick by the while singing Jampé-jampé Harupat.

In general, the kawih used for caring for children, as shown above, has short sentences and has rhymes in each of the lyrics. At this point, the indicator of early literacy values is attached to the kawih. One in eight of the strategies that can be done to build early literacy is by providing activities that increase children's awareness[4], [6], [8], [9]. From the sound of language or that words consist of the smallest unit of sound, namely the alphabet[7], [8], [10]. These activities include playing games and listening to stories, reciting poems, and songs that involve poetry, identifying words that end with the same sound[5], [16], [17].

In the study, it was also found that the kawih above provided phonological awareness within the Sundanese language. For example, children will begin to recognize seven vowels in Sundanese, which include letters a, i, u, e, o, é and eu. This is in line with the process of the child recognizing Sundanese words. In this section, kakawihan fulfills the early literacy indicators.Early literacy will provide initial literacy abilities that cover several points, some of which are as follows: (a) Grow phonological awareness for children. (b) Knowledge of letters. (c) Vocabulary. (d) Background knowledge. (e) Speaking ability[6], [16], [18].

Activities to develop early literacy must be done naturally in an environment that involves the closest people so that it is comfortable for children[5], [19], [20]. The environment of early literacy should be encompassed by interactions based on attention, love, and respect for the potency of children, so that children are comfortable talking and feeling respected[6], [8], [21]. The statement is certainly very obvious in the practice of parenting children. The practice can be seen when parents sing kakawihan, then touch love and soft caress always accompany hariring kakawihan which is sung by parents while inviting children to play. In this section, parents have also directed the child to a meaningful experience. Providing meaningful 
experiences to children/students can be done by inviting children to play traditional games[9], [22]-[24].

In its development, the pattern of parenting by using regional culture indirectly contributed to efforts to transfer culture to the next generation. Local culture was very important to be integrated with education because it aims to instill national and cultural identity in children[22]. The importance of instilling a regional culture about the impact of globalization that will erode the national identity. Therefore, the instilling of regional culture through education is a strategic step to improve the quality of future generations who are noble and virtuous. The study of local cultural wisdom needs to be developed in education because it has the benefit of giving birth to generations of competent and dignified people, reflecting cultural values, participating in building the national character, contributing to the creation of identity nation, and take part in preserving national culture [22], [23], [25] [26].

\section{CONCLUSIONS}

Based on the discussion above, it can be seen that kakawihan used to care for children contains early literacy values within the scope of Sundanese language and culture. Kakawihan which is used in caring for children, by the closest people, is also carried out with compassion will foster phonological awareness, knowledge of letters, and vocabulary of children's vocabulary in Sundanese. Besides, parenting by using kakawihan can contribute to the transfer of culture to children as the next generation.

\section{REFERENCES}

[1] S. Granlund et al., "Language-general and language-specific phenomena in the acquisition of inflectional noun morphology: A cross-linguistic elicited-production study of Polish, Finnish and Estonian,” J. Mem. Lang., vol. 107, no. May 2018, pp. 169-194, 2019.

[2] R. . Danadibrata, Kamus Basa Sunda. Bandung: PT Kiblat Buku Utama, 2015.

[3] K. Mokhtari, J. L. Neel, F. Kaiser, and H. H. Le, "Assessing the promise of a supplemental reading intervention for at-risk first grade students in a public school setting," Int. Electron. J. Elem. Educ., vol. 7, no. 3, pp. 281-300, 2015.

[4] E. Rodgers, J. V. D’Agostino, S. J. Harmey, R. H. Kelly, and K. Brownfield, "Examining the Nature of Scaffolding in an Early Literacy Intervention," Read. Res. Q., vol. 51, no. 3, pp. 345-360, 2016.

[5] B. R. Walgermo, N. Foldnes, P. H. Uppstad, and O. J. Solheim, "Developmental dynamics of early reading skill, literacy interest and readers' self-concept within the first year of formal schooling," Read. Writ., vol. 31, no. 6, pp. 1379-1399, 2018.

[6] J. V. D'Agostino, E. Rodgers, and S. Mauck, "Addressing Inadequacies of the Observation Survey of Early Literacy Achievement,” Read. Res. Q., vol. 53, no. 1, pp. 51-69, 2018.

[7] Y. N. Chang, P. Monaghan, and S. Welbourne, "A computational model of reading across development: Effects of literacy onset on language processing," J. Mem. Lang., vol. 108, no. June, p. 104025, 2019.

[8] L. Northrop, "Breaking the Cycle: Cumulative Disadvantage in Literacy," Read. Res. Q., vol. 52, no. 4, pp. 391-396, 2017.

[9] S. C. Kalindi, C. McBride, and L. Dan, "Early Literacy Among Zambian Second Graders: The Role of Adult Mediation of Word Writing in Bemba,” Read. Res. Q., vol. 
53, no. 1, pp. 7-27, 2018.

[10] J. L. Below, C. H. Skinner, J. Y. Fearrington, and C. A. Sorrell, "Gender Differences in Early Literacy: Analysis of Kindergarten through Fifth-Grade Dynamic Indicators of Basic Early Literacy Skills Probes," School Psych. Rev., vol. 39, no. 2, pp. 240-257, 2010.

[11] Muhammadi, Taufina, and Chandra, "Literasi Membaca untuk Memantapkan Sosial Siswa Sekolah Dasar," LITERA, vol. 17, no. 2, pp. 202-212, 2018.

[12] E. M. Schüller, L. Birnbaum, and S. Kröner, "What Makes Elementary School Students Read in Their Leisure Time? Development of a Comprehensive Questionnaire," Read. Res. Q., vol. 52, no. 2, pp. 161-175, 2017.

[13] W. E. Blanton, K. D. Wood, and D. B. Taylor, "Rethinking Middle School Reading Instruction: A Basic Literacy Activity," Read. Psychol., vol. 28, no. 1, pp. 75-95, 2007.

[14] J. R. Fraenkel, N. E. Wallen, and H. H. Hyun, How to design and evaluate research in education (8th ed.). New York: McGraw-Hill, 2012.

[15] S. D. Kusumah and A. Heryana, Kawih/Tembang Anak-Anak di Kalangan Kebudayaan Sunda dan Jawa. Jakarta: Pusat Penelitian Kebijakan Pendidikan dan Kebudayaan, Balitbang Kemendikbud, 2015.

[16] Y. Chang and P. Monaghan, "Quantity and Diversity of Preliteracy Language Exposure Both Affect Literacy Development : Evidence from a Computational Model of Reading Quantity and Diversity of Preliteracy Language Exposure Both Affect Literacy Development : Evidence from a Computatio," Sci. Stud. Read., vol. 23, no. 3, pp. 235253, 2019.

[17] Taufina and Chandra, "Developing the Big Questions and Bookmark Organizers (BQBO) Strategy-Based Reading Literacy Learning Materials in the 4th Grade of Elementary School,” Int. Conf. Sci. Educ. Teach., vol. 118, no. 5, pp. 857-864, 2017.

[18] J. W. Miller and M. C. McKenna, World literacy: How countries rank and why it matters. Routledge, 2016.

[19] W. Ngaka and F. M. Masaazi, "Participatory Literacy Learning in an African Context: Perspectives from the Ombaderuku Primary School in the Arua District, Uganda.," J. Lang. Lit. Educ., vol. 11, no. 1, pp. 88-108, 2015.

[20] M. ac. k. Yongnam Park1, "Examining South Korea's Elementary Physical Education Performance Assessment Using Assessment Literacy Perspectives.," Int. Electron. J. Elem. Educ., vol. 10, no. 2, pp. 207-213, 2017.

[21] M. Tok, "Examining pre-service teacher views on the implementation of screen-based writing instruction,” Int. Electron. J. Elem. Educ., vol. 7, no. 2, pp. 235-252, 2015.

[22] S. Nirmala, Rahman, and B. Musthafa, "Comparing Students' Critical Thinking Elementary School in Different Area with Utilizing FIVES Strategy,” Adv. Sci. Lett., vol. 24, no. 11, pp. 8357-8360, 2018.

[23] R. D. Puspita and Rahman, "Meningkatkan Kemampuan Membaca Pemahaman Berbantuan Pembelajaran tematik Terpadu Bernuansa Model InteractiveCompensatory,” J. Ilm. Pendidik. Dasar, vol. II, no. 2, pp. 200-211, 2017.

[24] Chandra, Mayarnimar, and M. Habibi, "Keterampilan Membaca dan Menulis Permulaan Menggunakan Model VARK untuk Siswa Sekolah Dasar," J. Inov. Pendidik. dan Pembelajaran Sekol. Dasar, vol. 2, no. 1, pp. 72-80, 2018.

[25] T. N. Hayati, Rahman, J. Sunanto, and T. Y. Pratama, "The Assessment of Communication Ability on Deafblind Students," Adv. Sci. Lett., vol. 25, no. 1, pp. 126-129, 2019. 
[26] K. Saddhono and S. Supeni. "The role of dutch colonialism in the political life of Mataram dynasty: A case study of the manuscript of Babad Tanah Jawi." Asian Soc. Sci. vol. 10 no. 15 pp. $1-7,2014$ 